極低温絶縁系の電気絶縁特性に及ぼす液体窒素流動の影響

\begin{tabular}{|c|c|c|}
\hline E 員 & 水野幸男 & （名工大 \\
\hline 学生員 & 水 野 & （名工大 \\
\hline 正 員 & 内 藤 克彦 & （名城大 \\
\hline
\end{tabular}

\title{
Effect of Forced-flowing Liquid Nitrogen on Electrical Insulation Characteristics of Cryogenic Insulation Systems
}

\author{
Yukio Mizuno, Kaname Mizuno (Nagoya Institute of Technology), \\ Katsuhiko Naito (Meijo University)
}

\begin{abstract}
The effect of forced-flowing of liquid nitrogen on (1) breakdown voltage of liquid nitrogen, (2) surface flashover voltage along polymeric rod immersed in liquid nitrogen and (3) lifetime to breakdown of polymeric film by partial discharges in liquid nitrogen were examined.

Breakdown voltage of forced-flowing liquid nitrogen was a littele higher compared with that of liquid nitrogen without forced-flowing. A slight increase of surface flashover voltage along acrylic rod was observed in forced-flowing liquid nitrogen. Lifetime to breakdown of polyethylene film subjected to partial discharges is longer in forced-flowing of liquid nitrogen. Considering the results of partial discharge measurements, the phenomena may be attributed to restraint of propagation of discharges by forced-flowing liquid nitrogen.
\end{abstract}

キーワード：流動，液体窒素，高分子，沿面放電，部分放電，寿命

\section{1.はじめに}

酸化物超電導体の出現以来, 超電導現象の電力機器など への応用を実現するため, 調查・研究が国内外で鋭意行わ れている．超電導電力機器の実現のためには，解決すべき 課題が幾つかあるが，極低温という過酷な㻴境に曝される 電気絶縁はその一つである，極低温における電気絶縁方式 として，スペーサと低温冷媒あるいはフィルムと低温冷媒 といった高分子材料と低温冷媒との複合系が提案され，絶

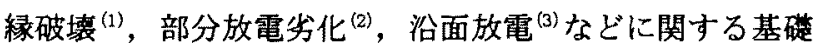
的研究が行われてきた。 これらの報告においては低温冷媒 の流動に関する明確な記述が無く, 低温冷媒は容器への流 入熱により自然対流しているものと推測される.

超電導電力機器の中には電気絶縁を兼ねる低温冷媒が強 制流動している場合もあり，冷媒の流動が複合系の電気絶 縁特性に及ぼす影㗽を評価することは，機器の絶縁設計上， 極めて重要と考えられる。しかしながら，低温冷媒の流動 が電気絶縁特性に及ぼす影響を系統的に調查した報告は無 いように思われる.

本論文では，液体空秦自体の絶縁破壊電圧，液体空素に 浸清した高分子表面の沿面放電電圧，液体空素中の部分放 電を介した高分子フィルムの絶縁破壊までの寿命に及ぼす
液体窒素流動の影響を, 自然対流の場合と比較して実娩的 に評価した, さらに, 部分放電測定結果に基づき, 液体㗧 素流動の効果を検討した.

\section{2. 実駰方法}

$<2.1>$ 液体空素の䊉粶破俵電压 液体公素自体の電 気絶縁特性に及ぼす流動の影響を評価するため, 流動時扔 よび自然対流時の液体空素の破塤電圧を測定した. 電極系 として，ステンレス製半球棒電極（直径 $6 \mathrm{~mm}$ ) -ステンレ 入製円盤電極（直径 $30 \mathrm{~mm}$ ）を使用した．また，真䤣製球（直 径 $25 \mathrm{~mm}$ ）一真鍮製球（直径 $25 \mathrm{~mm}$ ）電極系も使用した.

電極系を液体窒素に浸漬して定常状態に達した後, 電圧 上昇率 $1 \mathrm{kVrms} / \mathrm{sec}$ ，周波数 $60 \mathrm{~Hz}$ の交流上昇電圧を印加し て電極間隔 $2 \mathrm{~mm}$ までの液体窒素の破墙電圧を測定した。一 定条件下で 10 回の測定を実施した。

$<2.2>$ 沿面放電電圧 図 1 に示寸ように, 直径 $100 \mathrm{~mm}$ のステンレス製円盤電極系の中心部にアクリル円柱を挟ん だ.アクリル円柱の長さは $10 \mathrm{~mm}$, 直径は $10,20,40 \mathrm{~mm}$ と した.

電極系を液体窒素に浸漬し，電圧上昇率 $1 \mathrm{kVrms} / \mathrm{sec}$ ，周 波数 $60 \mathrm{~Hz}$ の交流上昇電圧を印加してアクリル表面の沿面放 電電圧を測定した。同一条件下で 10 回の測定を実施した. 


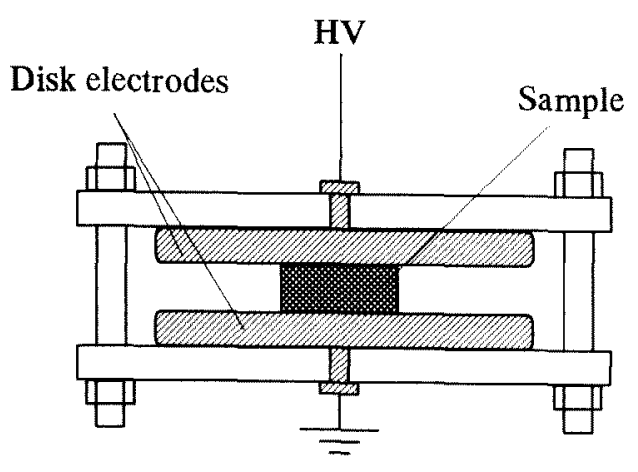

図 1 沿面放電電任測定用電極系

Fig.1. Electrode system for measurement of surface flashover voltage.

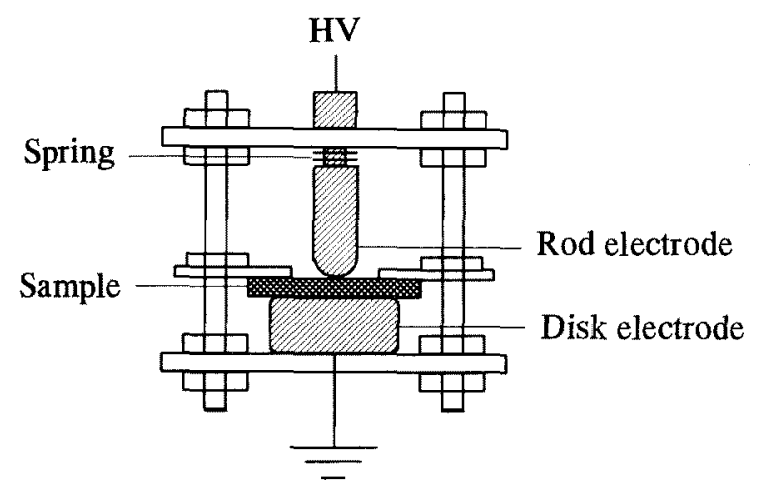

図 2 寿命試験用電極系

Fig.2. Electrode system for measurement of lifetime to breakdown.

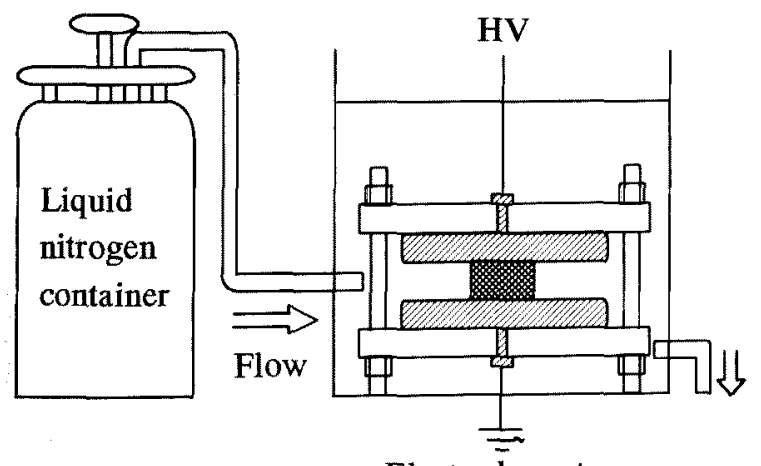

Electrode system

因 3 実龭系

Fig.3. Experimental setup

$<2.3>$ 絶縁破丧までの寿命 厚さ $100 \mu \mathrm{m}$ の低密度ポ リエチレンフィルム 1 枚の単,層試料, 厚さ $60 \mu \mathrm{m}$ と $40 \mu \mathrm{m}$ の低密度ポリエチレンフィルムを 1 枚ずつ重ねた積層試料 を実験に供した。図2に示すように，半球棒（ステンレス 製, 直径 $6 \mathrm{~mm}$ ) 一円盤 (ステンレス性, 直径 $30 \mathrm{~mm}$ ) 電極系 に試料を挟んだ。 円盤電極とフィルムとの間に液体空素が 侵入するのを防ぐため, 円盤電極上にシリコーングリース を薄く塗布してフィルムを貼り付けた，また，液体空素流
動時にもフイルムが円盤電極から剥㰚しないよう，押え板 を用いてフィルムを軽く押えつけた。棒電極先端は，ばね を用いてフィルム表面に軽く接触させてある.なお，積層 試料は 2 枚のフィルムを重ねただけであり, 液体等素浸清 時にはフィルムとフィルムとの間（層間）に液体窐素が侵 入する(4).

電極系齐液体公素に浸㣴し，601zの交流定電圧を棒電極 に印加して部分放電開始・消减電圧を测定した後, 液体公 素中の部分放電によりフィルムが絶縁破壊に至るまでの寿 命を求めた. 寿命試験中には部分放電測定装置（松栄電子 製，PD-Phase KHG-2) を用いて放電電荷, 放電発生頻度な どを測定した. 同一条件下で 10〜15 個の試料の測定を害施 Lた.

上記 3 種類のいずれの実験においても，120 リットルの 液体公素タンクを加圧することにより液体窒素を流動させ た. 実験系を図 3 に示す，液体窒素タンクからのホースを 低温容器に引込み, 液体窒素を放出させて低温容器内で流 動させた。低温容器の大きさは $200 \times 400 \times 700 \mathrm{~mm}$ であり, 液体空素供給用ホースは容器の壁面中央から低温容器内に 導入した，液体空素放出ノズルは直径 $7 \mathrm{~mm}$ で，実験時には 低温容器内に溜まった液体窒素中にある。液体窒素注入口 の反対側の低温容器壁面下方には, 直径 $25 \mathrm{~mm}$ の液体空秦排 出パイプが取り付けてある. 電極系を液体窒素放出ノズル から約 $150 \mathrm{~mm}$ 離れた場所に設置することにより，液体空素 放出時に含まれる気泡の影響を除いた. 電極付近では, 液 体空素がほぼ一椂に流動していること, 気泡はほとんど無 いことを目視で確認した。

本実験系において液体空素の流速を测定するのは困難で あり，便宜上，液体空素タンクの圧力を流動状態を表す指 標とした. $3 \mathrm{kgf} / \mathrm{cm}^{2}$ 加圧時の流速は $1 \mathrm{~m} / \mathrm{sec}$ 程度である。液 体空素の流動方向は各電極系の中心線に対して垂直方向て あり, 液体空素タンクの加圧圧力は $2 \sim 3$ 通り変化させた. なお，低温容器八の熱流入により䘸体空素が自然对流して いる状態においても同様の実験を実施し，液体窒素流動時 の結果と比較した。

\section{3. 実験結果}

\section{$<3.1>$ 液体臸素の絶縁破壊電圧}

電極間隔 $1 \mathrm{~mm}$ および $2 \mathrm{~mm}$ の棒一円盤電極系における液体窒 素の破填電圧に及ぼす液体窒素流動の影響を，それぞれ図 4 に示す. 図中の印は，20\%，50\%および80\%破垭電圧を表 す. 電極間隔が $1 \mathrm{~mm}$ の場合には, 液体窒素の破壊電纴は流 速にほとんど依存しない，しかしながら，電極間隔が $2 \mathrm{~mm}$ の場合には，自然対流時に比べて流動時の方が，わずかに 破壊電圧が高くなる。球一球電極系においても，同様の実 実験結果が得られた。

今回，実験を行った電極間隔および液体空素流速の範囲 では，液体窒素の絶縁破㐭電圧に及ぼす顕著な流動の効果 は認められなかった。 

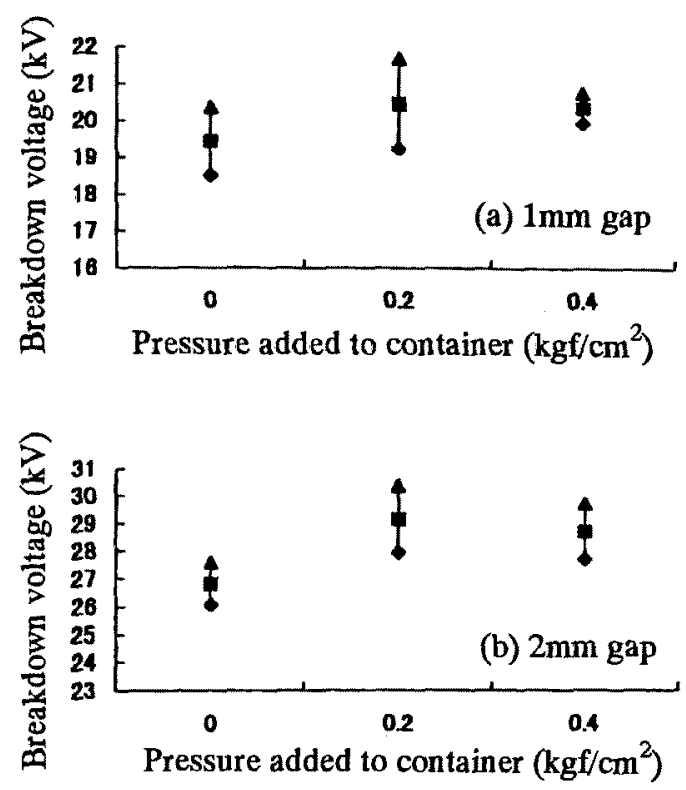

図 4 半球棒-円盤電極系の液体空素の絶縁破境電圧に

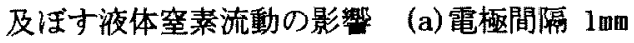
(b) 電極間隔 $2 \mathrm{~mm}$

Fig.4. Effect of forced-flowing on breakdown voltage of liquid nitrogen measured with hemisphericallytipped rod - disk electrode system. (a) gap distance $1 \mathrm{~mm} \quad$ (b) gap distance $2 \mathrm{~mm}$

$<3.2>$ 沿面放電電圧 アクリル円柱の沿面放電電圧 に及活す液体窒素流動の影響を, 図 5 に示す. 図中の印は, 20\%，50\%および 80\%沿面放電電圧を表す．直径 $10 \mathrm{~mm}$ のアク リル円柱の場合には液体窒素流動の影警はほとんど認めら れないが，直䍩 $20 \mathrm{~mm}, 40 \mathrm{~mm}$ の場合には，流速の上年ととも にわずかな沿面放電電死の上昇が癹められる.

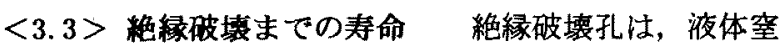
素流動の有無に拘わらず，棒電極字フィルムに投影した直 径 $6 \mathrm{~mm}$ の円内に存在した. 液体空素に流動時には, 自然対 流時に比べて下流側に絶緣破壊孔が存在する場合が多少增 加したが，液体窒素流動と絶縁破壊孔の位置との間に顥著 な相関は認められなかった。

寿命試験の結果はワイブル確率紙を用いて処理した。流 動時 (タンク圧力 $0.3 \mathrm{~kg} / \mathrm{cm}^{2}$ ) と自然対流時の平均寿命执よ びワイブル分布の形状パラメータ $\mathrm{m}$ を比較して表 1 に示す。 また，逆 $\mathrm{n}$ 乗則 $\mathrm{r}^{\mathrm{m}} \mathrm{t}=$ 一定 ( $\mathrm{V}$ : 印加電圧, $\mathrm{t}$ : 寿命) の $\mathrm{n}$ 值 も併せて示す。

同一電圧印加時には，液体空素が流動している場合の方 が絶縁破壊に至るまでの寿命が長くなることがわかる。積 層試料においても同槏の傾向が認められるが，単層試料の 場合より流動の影響が影著に現れているようである。形状 パラメータ $\mathrm{m}$ は 1 程度であり，偶発的故障形態を示唆する. $\mathrm{n}$ 值液体窒素流動の無い場合について報告されている值 (2) 已同程度である。
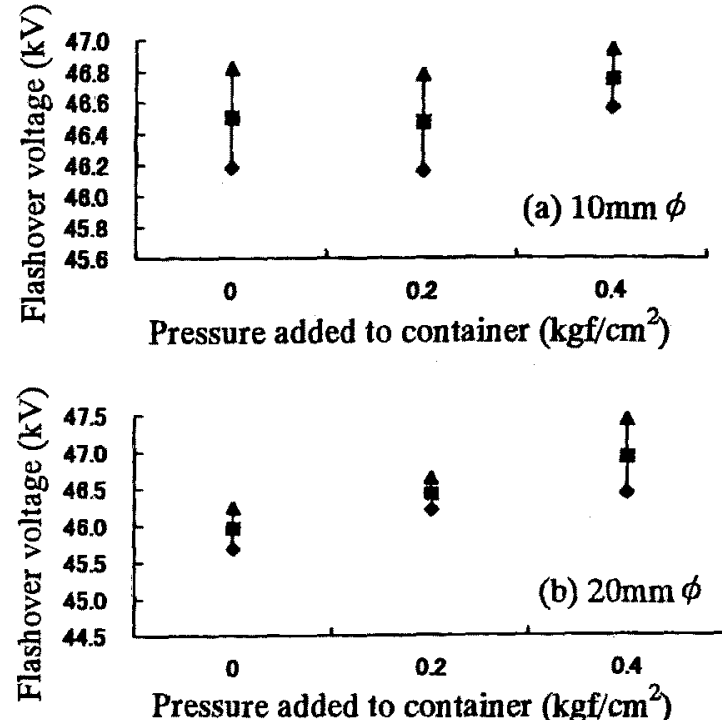

Pressure added to container $\left(\mathrm{kgf} / \mathrm{cm}^{2}\right)$

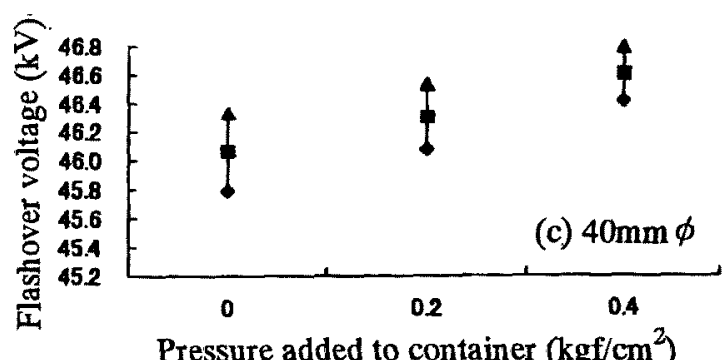

図 5 アクリル円柱の沿面放電電生に及ぼす液体窒素流動の

影姾 (a) 直径 $10 \mathrm{~mm}$ (b) 直径 20mm (c) 直径 $40 \mathrm{~mm}$

Fig.5. Effect of forced-flowing of liquid nitrogen on surface flashover voltage along acrylic rod.
(a) $10 \mathrm{~mm} \phi$
(b) $20 \mathrm{~mm} \phi$
(c) $40 \mathrm{~mm} \phi$

表 1 寿命試験の結果

Table 1 Results of life tests.

\begin{tabular}{|c|c|c|c|c|c|}
\hline & 流 動 & $\begin{array}{c}\text { 印加電圧 } \\
\text { [kVxms] }\end{array}$ & $\begin{array}{c}\text { 平均寿命 } \\
\text { [sec] }\end{array}$ & $\mathrm{m}$ & $\mathrm{n}$ \\
\hline \multirow{4}{*}{$\begin{array}{l}\text { 単 } \\
\text { 層 }\end{array}$} & \multirow[t]{2}{*}{ なし } & 12 & 995 & 1.1 & \multirow[t]{2}{*}{12} \\
\hline & & 13 & 380 & 1.3 & \\
\hline & \multirow[t]{2}{*}{ あり } & 12 & 1520 & 1.2 & \multirow[t]{2}{*}{13} \\
\hline & & 13 & 535 & 1. 3 & \\
\hline \multirow{4}{*}{ 層 } & \multirow[t]{2}{*}{ なし } & 12 & 1436 & 1.1 & \multirow[t]{2}{*}{11} \\
\hline & & 13 & 588 & 1.1 & \\
\hline & \multirow[t]{2}{*}{ あり } & 12 & 2921 & 1.1 & \multirow[t]{2}{*}{10} \\
\hline & & 13 & 1357 & 1.3 & \\
\hline
\end{tabular}

流動なし：自然対流

流動あり：タンク圧力 $0.3 \mathrm{~kg} / \mathrm{cm}^{2}$

寿命に及ぼす液体空素流動の影響を単層試料について調 べた結果を，各電圧印加時の自然対流時の寿命を 1 として 規格化して図 6 に示す.タンク圧力 $0.1 \mathrm{~kg} / \mathrm{cm}^{2}$ 時には液体 


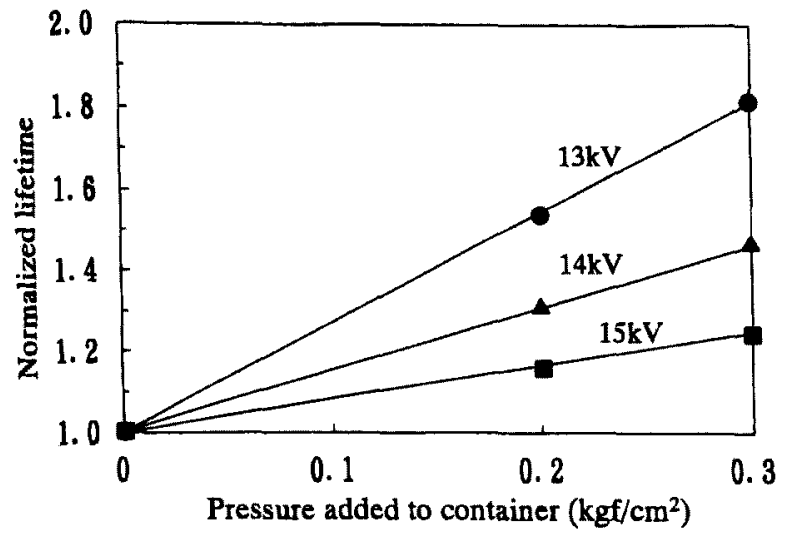

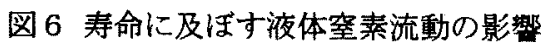

Fig.6. Effect of forced-flowing of liquid nitrogen on lifetime to breakdown.

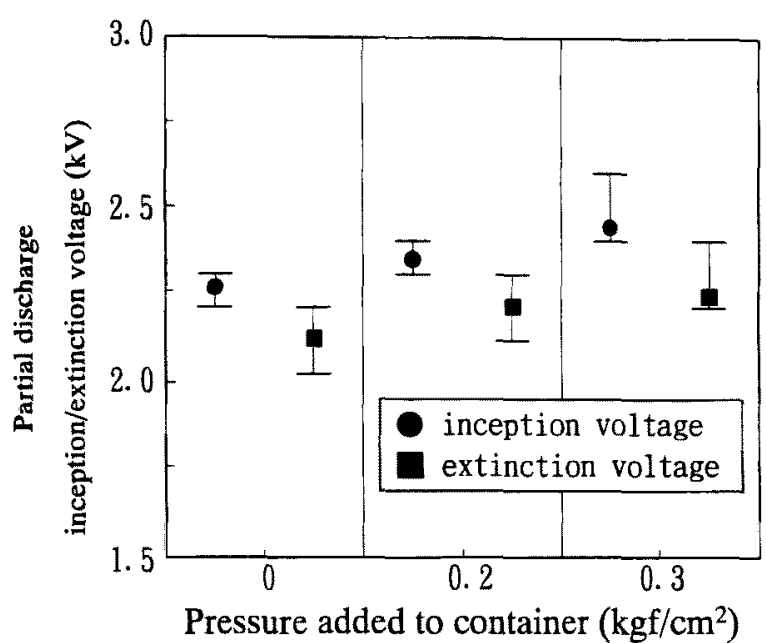

図 7 部分放電開始・消隇電圧に及ぼす液体窒素 流動の影㜅

Fig.7. Effect of forced-flowing of liquid nitrogen on partial discharge inception and extinction voltages.

空素の流動が不安定で，信頼性のあるデータを得ることが できなかった，実験を行った範曲では，印加電圧の大きさ に関係なく，液体空素タンク圧力と寿命との間に直線関係 が認められるが, 印加電圧が低いほど液体空素流動の影御 が大きいことがわかる.

以下，部分放電測定の結果について述べる．部分放電開 始・消滅電壬に及ぼす液体空素流動の影響它，单層試料の 場合について図 7 に示す．液体窒素流動時には自然対流時 に比べ部分放電開始・消减電圧ともに高くなるが, 液体 空素タンク圧力が高いほど上昇の程度は大きい。

1 サイクル当りの平均放電パルス数と印加電圧位相との 関保の典型例を図 8 に示す。これは液体空溸流動時（タン ク圧力 $0.3 \mathrm{~kg} / \mathrm{cm}^{2}$ ) に単層試料に $13 \mathrm{kV}$ を印加した場合の結 果である. 印加電圧の位相が 20-80 度付近および 190-280

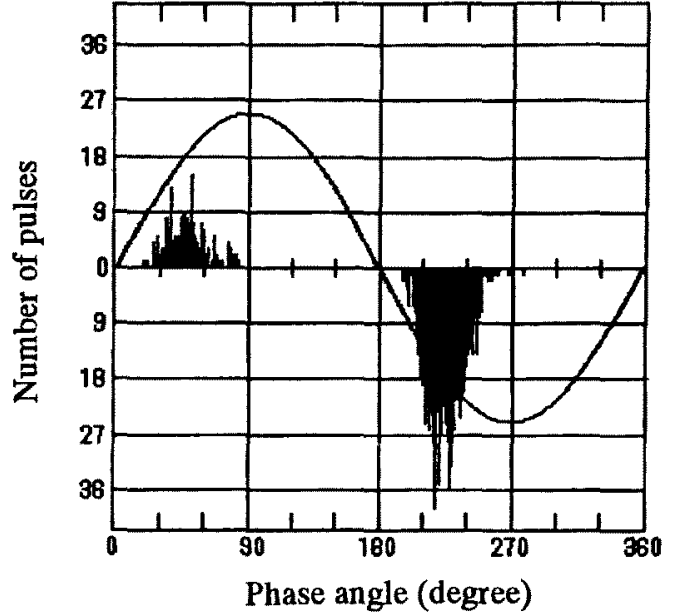

図 81 サイクル当りの平均放電パルス数と印加電圧 位相との関保

Fig.8. Relation between average number of pulses per cycle and phase angle of applied voltage.

度付近で放電功発生していること，負極性放電の方が多く 発生していることがわかる，自然対流時の単層試料および 積層試料においてもほぼ同様の傾向が認められた。

单層試料における自然対流時および流動時の典型的な累 積放電電荷量および累積放電パルス数の時間変化を図 9 に 示す. 流動時のタンク圧力は $0.3 \mathrm{~kg} / \mathrm{cm}^{2}$, 印加電圧は $13 \mathrm{kV}$ である. 液体窒素流動時には, 自然対流時に比べて放電電 荷，放電パルス数が少ないことがわかる，また，自然对流 時には累稓放電電荷および累積放電パルス数は, 時間とと もに增加しているが，液体窒素流動時に性時間に対して増 加しない時間帯があり，部分放電が発生していないことを 示唆する. 積痼試料についても同様の傾向が認められた.

以上述べたように，液体空素中の部分放電を介したフィ ルムの絶縁破壊までの寿命および寿命試験中の部分放電特 性には，顕著な液体窐素流動の影響が認められた。

\section{4. 液体辤素流動の影䇾}

まず，部分放電を介したフィルムの絶縁破壊までの寿命 に及ぼす液体窒素流動の影響について検討する。前章で述 べたように, 液体窒素流動時屿自然対流時に比べて, 部分 放電開始・消诚電圧が高く，放電電荷量，放電パルス数が 少ない，液体萃素流動により部分放電が進展しにくくなる ため，このような結果が得られるものと考えられる.この 場合, 液体空秦の流動が激しいほど効果が顥著になると予 测されるが，図6に示した寿命試験結果にはその傾向が認 められる。

図 9 において，液体堂素流動時には累積放電電荷およ び累皘放電パルス数が時間に対して増加しない時間帯があ り，液体窒素流動により部分放電が停止していることを意 昧する。自然对流時にはこの現象は認められない。これら の結果は，液体窒素流動により部分放電発生が抑制されて 

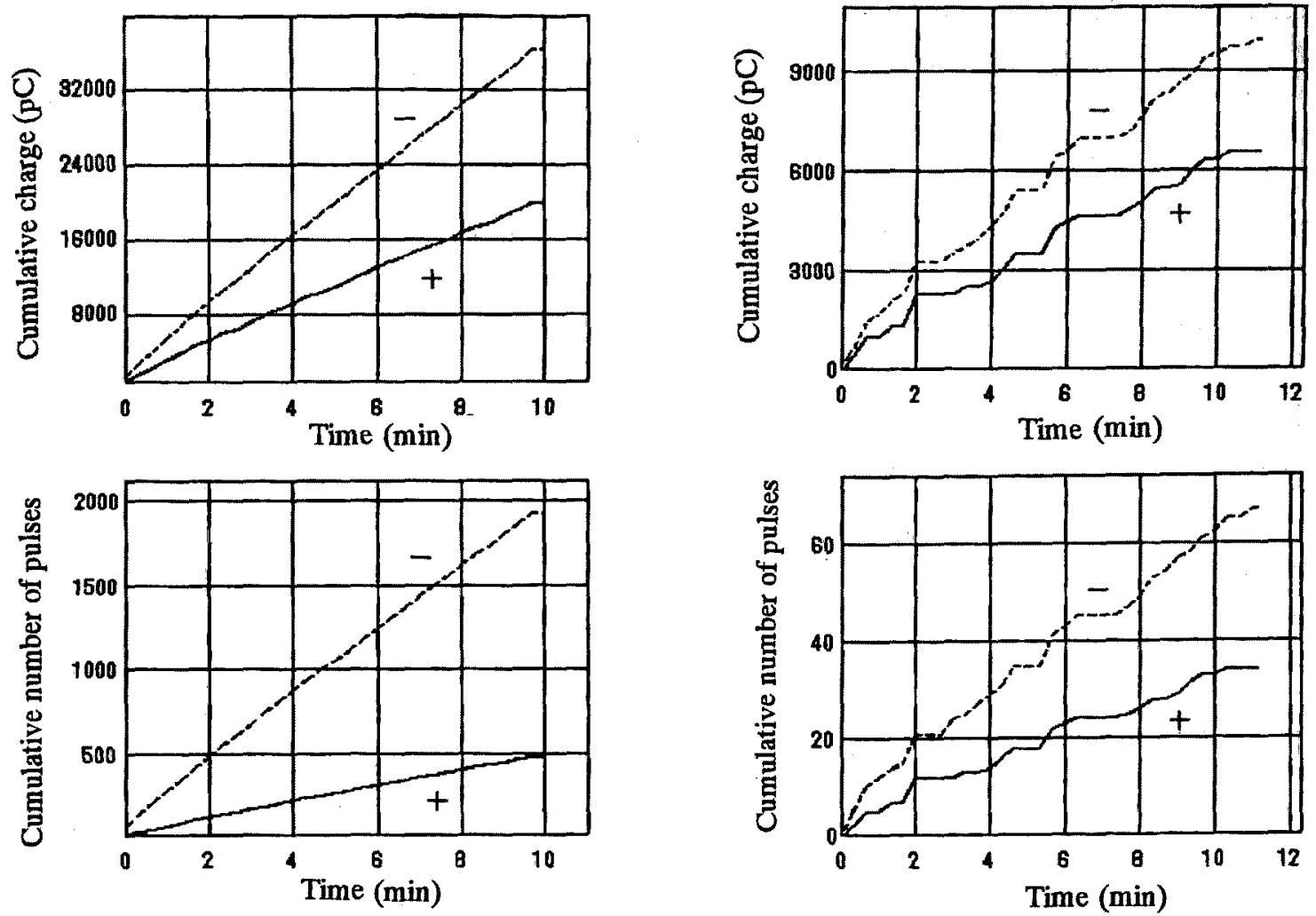

(a) 自然対流時

(b) 流動時

図 9 累楮放電電荷および累積放電パルス数の時間変化

Fig.9. Time variation of cumulative charge and cumulative number of pulses. (a) without forced-flowing

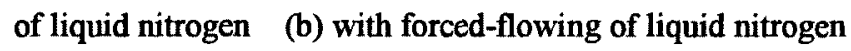

いることを示唆する，累積放電電荷を累積放電パルス数で 除した放電パルス当りの平均放電電荷は, 液体至素流動時 の方がはるかに大きい。このことから, 液体室素流動によ り放電電荷の比較的小さい放電が抑制されるものと推測さ れる,

次に積層試料における液体窒素流動の影響を検討する。 自然対流状態では，印加電王が低い場合には積層試料の方 が単層試料よりも寿命が長く，印加電圧が高い場合には逆 の傾向を示すことが報告されている(4). 印加電圧が低い場 合には層間にある液体空素中で放電は発生せず，棒電極先 端の放電が上のフィルムを破壊すると層間で広がり，次い で下のフィルムを破壊するのに対し，印加電圧が高い場合 には層間に存在する液体窒素中でも放電が発生するため, 上のフィルムは棒電極先端の放電と層間の放電とに曝され て少化が促進されるためである。

表 1 を見ると，積層試料の力が単層試料に比べて寿命が 長いことから，本実験で使用した印加電圧では層間の液体 窒素中ではほとんど放電は発生していないものと推測され る.この場合, 液体窒素流動により棒電極先端の放電は単 層試料と同様に抑制される，さらに，上のフィルムが絶緣 破壊して層間の液体空素中で放電が発生した場合には，層
間に存在する液体空素の流動により層間での放電が抑制さ れると推測される、従って，積層試料では単層試料に比べ て液体空素流動の効果が顕著に現れるものと考えられる。 なお，液体空素自体の絶縁破壊電圧および高分子の沿面 放電電圧に及ぼす液体窒素流動の効果が余り認められない のは，絶縁破銅電王や沿面放電電圧が寿命試験の印加電圧 に比べて高いため放電のエネルギーが大きく，液体葟素流 動により放電の進展が抑制されにくいいことが原因の一つ と考えられる.

\section{5. むすび}

液体窒素の絶縁破壊電圧, 液体窒素に浸瀆した高分子の 沿面放電電圧および液体営素中の部分放電を介した高分子 フィルムの絶縁破壊に至るまでの寿命，に及ぼす液体空素

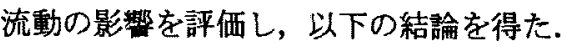

(1) 液体空素の絶縁破壊電圧注，電極間隔 $2 \mathrm{~mm}$ の場合，液 体窒素流動時には自然対流時に比べてわずかに上昇し た。実験した流速の範囲では流速依存性は認められな かった.

（2）液体窒素に浸溃した高分子円柱の沿面放電電圧は，直 径が大きい場合に流体窒素流動時に江自然対流時に 
比べてわずかに上昇した.

(3) 液体窒素中の部分放電を介した高分子フィルムの絶縁 破壊までの寿命は, 液体窒素流動時の方が自然対流時 に比べてかなり長くなった.この傾向は，積層試料に おいてより顥著に認められた.

(4) 液体至素流動時には, 自然対流時に比へて部分放電開 始・消滅電圧は高くなり, 累積放電電荷量, 累積放電 パルス数は減少した.

(5) 流動液体窒素の流動により部分放電の進展が抑制され るため, 電気絶稼特性が向上するものと考えられる.

本研究の一部は, 文部省科学研究費補助金ならびに（財） 中部電力基礎技術研究所の援助を受けて行われたことを付 記し, 謝意を表する. また, 実験にご協力いただいた名古 屋工業大学卒業生の木村貴幸氏, 浅田和弘氏に感謝する。

(平成 10 年 9 月 24 日受付, 平成 10 年 12 月 24 日再受付)

\section{文 献}

(1) 例えば, A.Bulinski and J.Densley, “The Impulse Characteristics of Electrical Insulation Operating at Cryogenic Temperatures", IEEE. Trans. on Electrical Insulation, Vol.15, No.2, pp.89-96, 1980.

(2) 例えば, Y.Mizuno, M.Nagao, M.Kosaki, N.Shimizu and K.Horii, "Interaction of Partial Discharge Streamers in Cryogenic Fluids with Polymeric Films", IEEE Trans. on Electrical Insulation, Vol.23, No.4, pp.689-695, 1988.

(3) 例えば, Y.Mizuno, T.Kimura and KNaito, "Surface Flashover Characteristics along Polymeric Rod Partially Immersed in Liquid Nitrogen", IEEE Trans. on Dielectrics and Electrical Insulation, Vol. 5, No.6, pp. 809-813, 1998.

（4）水野, 近藤, 清水, 小崎, 堀井, 「液体窒素中の多層 ポリエチレンフィルムの部分放電による絶縁破壊」, 電気学会論文誌 A, 105 巻, 8 号, pp.413-420, 1985.
水野幸男 (正員) 1958 年 7 月 8 日生まれ. 86 年 3

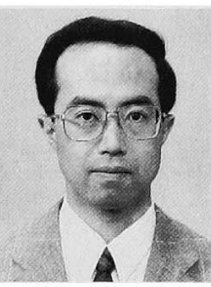
月名古屋大学大学院工学研究科博士後期 課程終了. 同年豊橋技術科学大学 電気・ 電子工学系助手. 93 年 11 月名古屋工業 大学電気情報工学科助教授, 現在に至る. 主として，極低温電気絶縁，外部絶縁に 関する研究に従事. 工学博士. 低温工学 会, IEEE 会員.

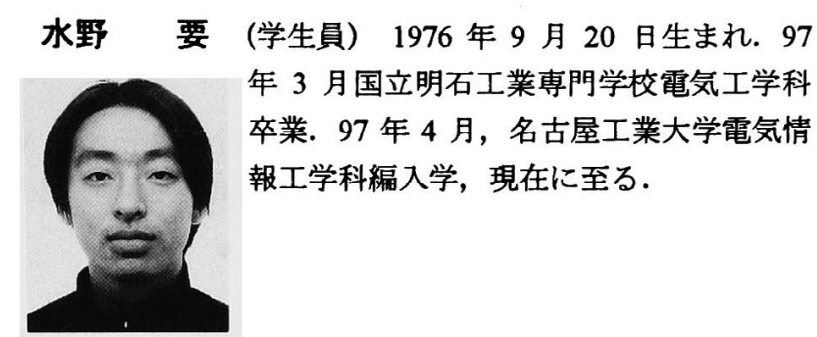

内藤 克彦 (正員) 1934 年 12 月 24 日生まれ. 60 年

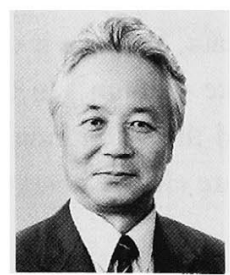
3 月名古屋大学大学院工学研究科修士課 程修了. 同年 4 月日本碍子株式会社就職. 高電圧研究所長, 技師長, 理事を経て 91 年 11 月同社退職. 直ちに名古屋工業大学 電気情報工学科教授. 98 年 4 月名城大学 理工学部電気電子工学科教授. 主として, 外部絶縁, 信頼性, 電磁環境に関する研究に従事. 工学博 士. IEEE Fellow, CIGRE 会員. 